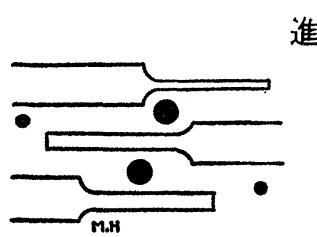

総 説

\title{
最近の高速度鋼 (I)
}

近藤 正 男*

\section{1. 緒言}

高速度鋼が 世に出てすでに70 年近くになる。いわゆ るタングステン系高速度鋼は 18-4-1 タイプ(第 1 表備考 参照）を標準として，Co の添加，Moによる代用が研究 せられ，第 2 次世界大戦前後には注㜔完成したので，本 誌に相次いでその集録が行なわれた(1)(2)，当時，モリブ デン系高速度鋼は熱処理条件飞敏感で，実用歩留りが低 く，まだ代用の域を出て招らなかつたが，その後鋼種の 開発之技術の進歩に上つて，その優秀性が買われ，1945 年当時アメリカで $\mathrm{W}$ 系 $60 \%$ ，Mo 系 40\% であつた使用 量が，1951 年にはMo 系 $85 \%$ 飞上昇した。欧州でもわ が国でもMo 系の普及が続き，ほとんどMo 系が実用に なつていなかつたわが国でも，1962 年には 43\% まで上 昰し，との後さらに上升している。近く日本工業規格 (JIS) の高速度鋼規格が大幅に Mo 系を增補するよ5〔第 1 表改 JIS 案(1966) 参照] 審議が進んでいる現在, その 後の高速度鋼について紹介することも無駄ではないと思 了.

高速度鋼はしばしば超硬合金と比較される。高速度鋼 は超硬合金よりカタサは低い(超硬合金ビッカース・カ タサ 1200 1300 に対し, 高速度 鋼は 900 前後, 最近は 1000 を超す鋼種も出来た) ・ が強鞁性と低廉な洒額と， 良好な再研削性の故に独自の用途を持つて物り，ドリ ル・ホブ・ブローチなど，切削速度の早くない複雑な形状 の工具には多量に使用せられており，また木工用・ナイ ロンのような非金属材料の切削に，金型材料，高温で使 用せられる航空機用軸受材料，ディーゼルエンジンの injector などにも使用せられ，依然として大量に使用せ られている（わが国で月産高速度鋼 $500 \mathrm{t}$ 飞対し，超硬 合金約 $40 \mathrm{t}$ )。

\section{2. 種 類 (元素の 影響)}

日本工業規格 (JIS) に関係の专る鋼種と，下記に引用与 る鋼種の大略主要成分を, 日本，アメリカ，イギリス，

* 株式会社不二越; 技術研究所長

（1）佐藤：金属学会誌，5(1941)，81，154，197，231, $281,368,415,468,528,589,631$.

（2）大和久: 金属学会誌, 8 (1944) , 1, 21,37,55,101, 140,172 .
酒独, ソ連各国の規格記号と対心させて第 1 表に示 1 た。型式記号は以前には18-4-1 というょうに，タング ステン系は大略重量\%で W-Cr-V-Co 量を示し，モリブ デン系は同じくW-Mo-V-Coで示した (3)(31) が，1960 年: 以降の文献では $\mathrm{W}-\mathrm{M} 0-\mathrm{V}-\mathrm{Co}$ で示してあるのが多い(53) (54).

規格化され，またメーカーが㹈造品目としている鋼種 は全部で約 70 種あるが，そのうちアメリカでは，一般 目的に T 1, M 1，M 2, M 10, 耐摩耗性を主とする用途 飞 M 3, M 4, M 7, 超高級に T 5, T 15, M 34, M 35, M 36, M 41〜M 44 のどれかが注とんどの仕事をしている といつてよい，矢の使用量は M 2,M 1 が各全体の 40\%， T 1 が 10\% 前後である。わが国では SKH 2 とSKH 9 と がほとんぞ大部分で，高級用途に SKH 3, SKH 4 A が使 用せられる。その他の傾向はアメリカと同様と見てよ w.

W采はいわ肪る 18-4-1 棒準タイプの変形であつて, V

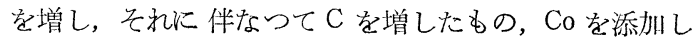
あるいはそれとともにVまたはWを增したものがあり， とくに 12-0-5-5 (T 15) は高V, 高Cで Co を添加して拉 り, 耐摩耗性の高いものである. Mo 系には 2-9-1 (M1) の変形である M 7, M 30,M 34 などがあり, 6-5-4 (M 2) の变形である M 3, M 4 M 35，M 36 などがある.M 15 は高Vで Co を添加し，W系の T 15 亿対応するものと 見て上い。矢の他，用途に匛じて，メーカーではさらに その製造成分範囲を狭くしたり，多少ずらせている，第 2 表にその一例を示した。

高速度鋼中の $\mathrm{C}$ 量は最も古くて，かつまた最も新らし い問題である.

（1）C量は普通 $0.70 〜 0.90 \%$ でるが，同一等入温 度でも，C量が高いほど，燅戻 2 次硬度の最高値が高く なる。第1図は $16-0-1,1280^{\circ} \mathrm{C}$ 焼入の場合であるが, $1260^{\circ} \sim 1290^{\circ} \mathrm{C}$ 焼入でもこの傾向は同じである。オース テナイト結晶粒度は $\mathrm{C}$ 量, 焼入温度ともに高い注ど粗々 なるが，焼入温度の影響の方が大きい(4) (第 2 図).

常温の勒性はC 量の增加によつて減少するが，高温に 怙ける引張強さ，伸びはほとんど変らず，高温衝撃値は

(3) E. Houdremont: Handuch der Sonderstahlkunde, (1956) , 1014.

（4）片桐，町：金属学会誌，18(1954)，401. 


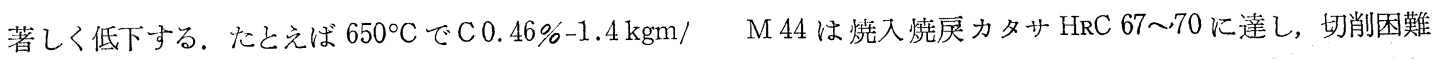
$\mathrm{cm}^{2}$ から C $0.85 \%-0.3 \mathrm{kgm} / \mathrm{cm}^{2}$ へほと儿ど直線的に低 な金属や合金鋼の切削汇適している。この鋼のノッチな

第 1 表高速度鋼の規格記号と

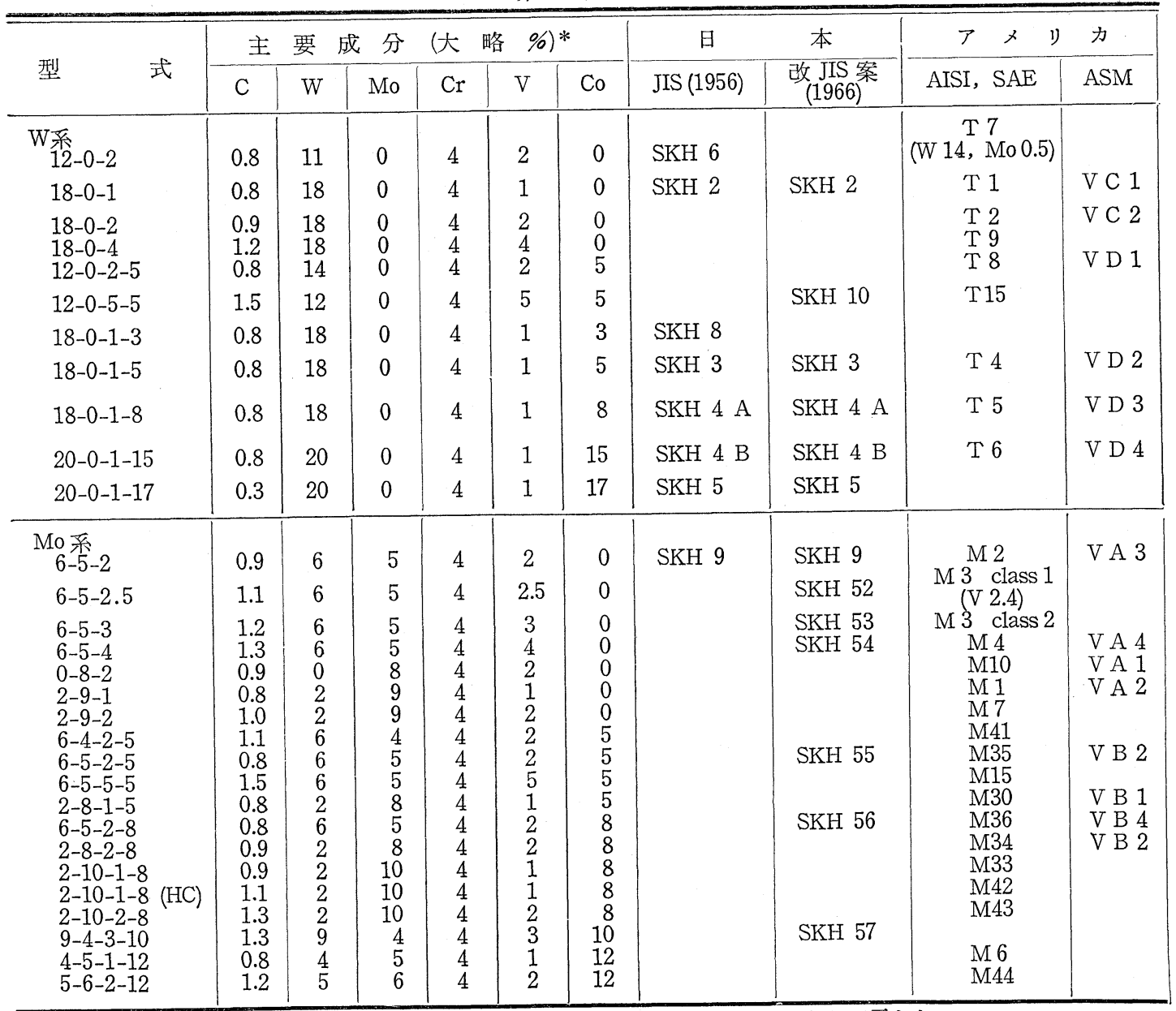

* 大体の值である，かなり異なつているのは各規格記号の下にカッコをして示した.

下, $700^{\circ} \mathrm{C}$ では C $0.46 \%-2.3 \mathrm{kgm} / \mathrm{cm}^{2}$ から C $0.85 \%$ $1.0 \mathrm{kgm} / \mathrm{cm}^{2}$ へ低下する(5). 西独では Cを従来より約 $0.2 \%$ 高めることによつて, 含有炭化物を増し, 焼入力 タサをロックウエル C 2 3 高め, 耐摩耗性, 切削性能 を高く出来ると報告している ${ }^{(6)}$. 高 W, 高 $\mathrm{Co}$ 高速度鋼 (20-0-2-20 または20-0-2-25) では C 0.6\% まではC量 の上年とともに切削耐久力が増すが，とれを越すと減少 するという報告もある(7). Fletcher, Wendell は M 2, M 10 ベースに护けるC量の影響について第3 図のような 結果を得ている(8). 高Cの新しい鋼種 $\mathrm{M} 41, \mathrm{M} 42, \mathrm{M} 43$,

（5）山中，日下，北原：鉄と鋼，43(1957)，720.

(6) O.Mülders and E.G.Sickel: DEW Techn. Ber,2 (1962), 7 .

（7）小柴：金属学会誌, 7 (1943), 434 .

(8) S. G. Fletcher and C.R. Wendell: Metals Engn. Quarterly, 6 (1966), Feb.1.
しアイゾット衝撃值は, 焼入焼戻カタサ $\mathrm{HRC} 67 \sim 69$ の とき $10 \sim 20 \mathrm{ft}-1 \mathrm{~b}(1.4 \sim 2.8 \mathrm{kgm}), \mathrm{HRC} 65$ のとき M 2 の 約 $1 / 2$ で, T 15 やSKH 4 A とほぼ同じ值である，この 鋼種の製造には，成分のコントロールに十分な注意が必 要である上に, 融点が低いので, 在延・鍛造温度の上限 を厳密に制限しなければならない，マシナビリテイは高 硬度の割によく，T15 よりはるかに容易であり，被研削 性も悪くない.この鋼種の焼入温度は予熱 $750^{\circ} \sim 850^{\circ} \mathrm{C}$, 本熱 $1190^{\circ} \sim 1215^{\circ} \mathrm{C}\left[\mathrm{M} 44\right.$ は $\left.1200^{\circ} \sim 1225^{\circ} \mathrm{C}\right]$, ソルト バス加熱のときは，それ枈れそれより $15^{\circ} \mathrm{C}$ 下げる。焼 戻は M 41 と M 44 とは $540^{\circ} \sim 600^{\circ} \mathrm{C}, \mathrm{M} 42$ と M 43 は $510^{\circ} \sim 560^{\circ} \mathrm{C}$ にとる. M 42 に例をとると, $518^{\circ} \mathrm{C} \times 2 \mathrm{hr}$ 3〜4 回で最高硬度を得, 3 回の焼戻で残留オーステナイ トは2〜4\%に減少する。 
(2) $\mathrm{C}$ 量と密接な関係沈あるのは $\mathrm{V}$ 量である。 $\mathrm{C}$ と $\mathrm{V}$ との関係については,つぎの関係が求められている。

主要 成 分

\begin{tabular}{|c|c|c|c|}
\hline イギリス & 独 & 連 & \\
\hline BS & DIN & GOST & 拥 \\
\hline . & $\begin{array}{l}3316 \mathrm{ABC} \text { II } \\
3355 \mathrm{~B} 18 \\
3357 \mathrm{C} 18 \\
3251 \mathrm{E} \mathrm{Co} 5 \\
3202 \mathrm{EV}_{4} \mathrm{Co} \\
3245 \mathrm{E} 18 \mathrm{Co} 3 \\
3255 \mathrm{E} 18 \mathrm{Co} 5 \\
\quad \mathrm{~V} 2) \\
3265 \mathrm{E} 18 \mathrm{Co} 10 \\
\text { (Co } 10) \\
\mathrm{E} 18 \mathrm{Co} 15 \\
\text { (V } 2 \text { Mo 1.5) }\end{array}$ & $\begin{array}{l}\text { ES } 347, \text { R } 9 \\
\text { R } 18 \\
\text { R } 18 \text { F } 2 \\
\text { R } 9 \text { K } 5 \text { (W 9) } \\
\text { R } 10 \mathrm{~K} 5 \mathrm{~F} 5 \\
\text { (C 1.4, W 10) } \\
\text { R } 18 \text { K } 5 \text { F } 2 \\
\quad(\mathrm{~V} 2) \\
\text { RK } 10\end{array}$ & $\begin{array}{l}\text { 標準 タイプ } \\
\text { 18-4-1相当 }\end{array}$ \\
\hline & $\begin{array}{l}3343 \text { DMo } 5 \\
3344 \text { EMo } 5 \text { V } 3 \\
3346 \text { BMo } 9 \\
3243 \text { EMo } 5 \text { Co } 5\end{array}$ & & \\
\hline
\end{tabular}

第2 表 モリブデン系高速度鋼 M 3 の变形例

\begin{tabular}{|c|c|c|c|c|c|c|}
\hline \multirow{2}{*}{ タイプ } & & \multicolumn{5}{|c|}{ 化 学 成 分 (\%) } \\
\hline & & C & W & Mo & $\mathrm{V}$ & Co \\
\hline M 3 & AISI-SAE & $1.00 \sim$ & $5.50 \sim$ & $4.75 \sim$ & $3.75 \sim$ & - \\
\hline M $3{ }_{1}$ & AISI & 1.05 & 6.00 & 5.00 & 4.00 & - \\
\hline $\mathrm{M} 3{ }_{1}$ & Latrobe & 1.02 & 6.00 & 6.00 & 4.00 & - \\
\hline $\mathrm{M} 3{ }_{2}$ & AISI & 1.20 & 6.00 & 5.00 & 4.00 & $\ldots$ \\
\hline $\mathrm{M} 3{ }_{2}^{2}$ & Latrobe & 1.20 & 6.00 & 6.00 & 4.10 & - \\
\hline
\end{tabular}

$\mathrm{C}(\%)=0.5 \%+0.2 \mathrm{~V}(\%) \quad$ Kinzel, Burgess (1932) ${ }^{(9)}$ $\mathrm{C}(\%)=0.19 \%+0.017 \mathrm{~W}(\%)+0.22(\%)$

佐藤, 西沢, 村井 (1959) (10)

(9) A.B.Kinzel and C.O.Burgess: Trans. AIME, 100 (1932), 257 .

（10）佐藤，西沢，村井：鉄と鋼，45(1959), 511 .

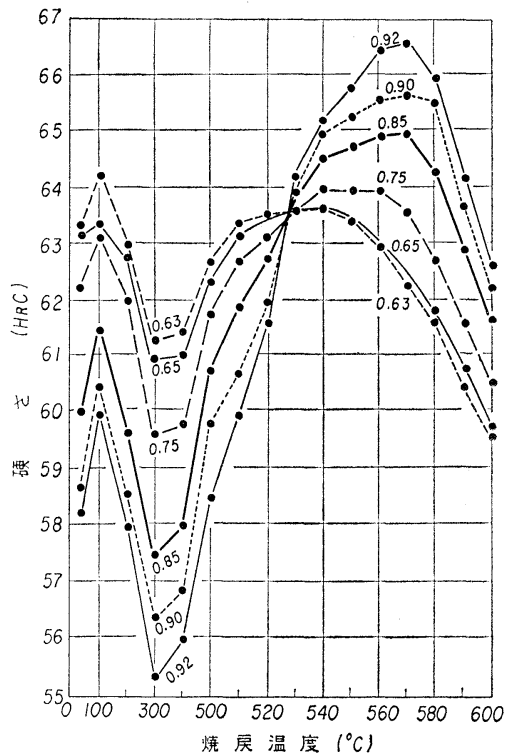

第 1 図高速度鋼 (16-0-1)のC 量と焼入 . 焼戻カタサ

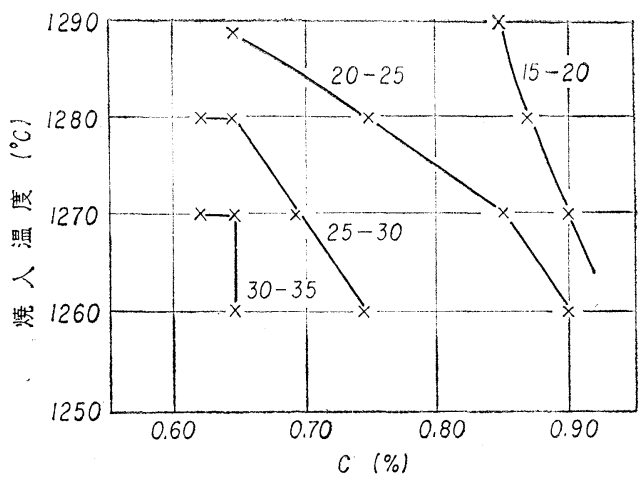

第 2 図高速度鋼 (16-0-1) のC 量之結晶粒度: (5\% Nital etching)

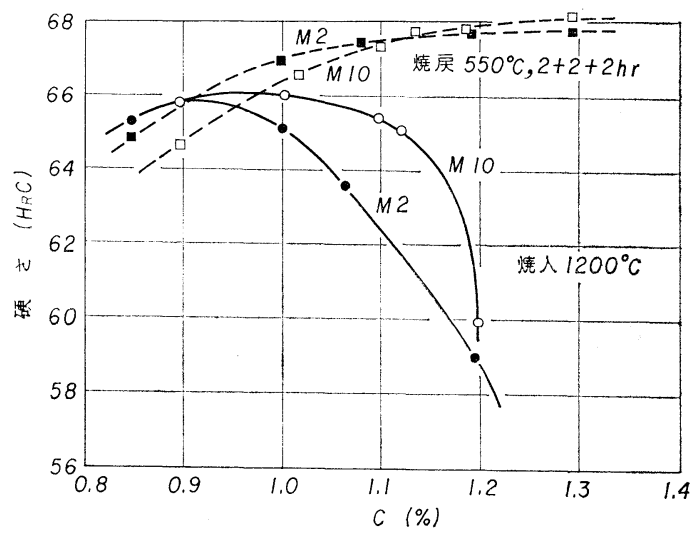

第3 図 M 2 と M 10 との焼入カタサ, 焼入焼戻 カタサに掠よ洔すC 量の影響 
また Blickwede らはV 1\%についてCを $0.25 \%$ 増さね ばならないといつている(1950)(11). 彼らは C と V の量

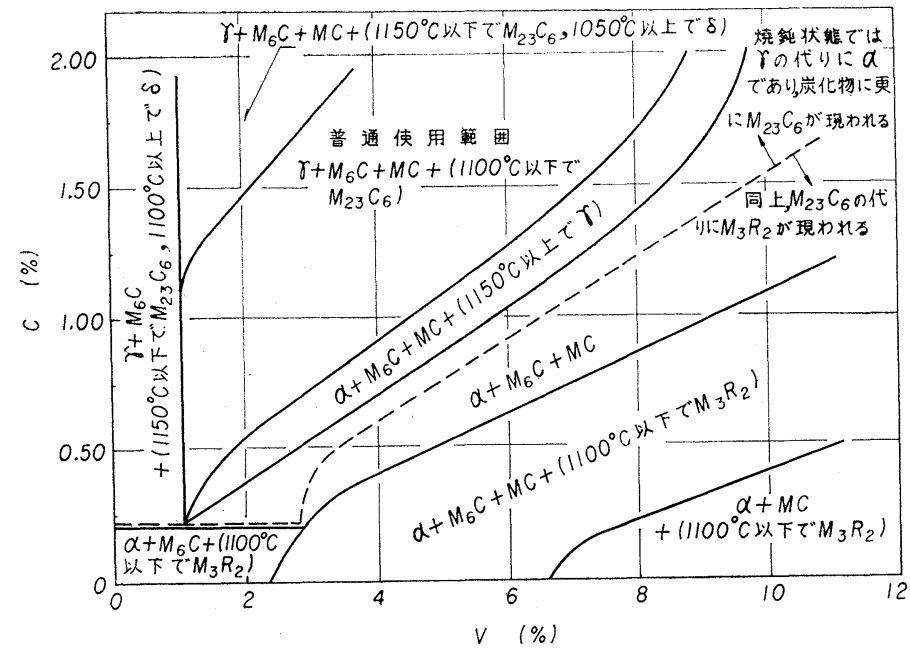

実線は $930^{\circ} \sim 1260^{\circ} \mathrm{C}$ に 6 分保つた後の顕微鏡組織, 破 線は焼鈍状態(常温)，6\% W, $5 \% \mathrm{Mo}, 4 \% \mathrm{Cr}$ 第 4 図高速度鋼に和ける $\mathrm{V}$ 量と $\mathrm{C}$ 量の影響
22\%どまりであるが，Mo 量は次第に多量に使用せられ るようになり，10\%に達した。 たとえば M 10\%+W 10 $\%$ C $1.1 \%$ 以上でCo を添加したもの は適当な焼入焼戻によつて HRC 70 に 達する，モリブデン高速度鋼は前記の ように加熱の際, 脱モリブデンととる に脱炭を起しやすいが，Mo $5.5 \%$ 以 下, W 5〜6\%にした高速度鋼は，脱 炭が少ない(15)。 またMo 系とW系との $550^{\circ} \mathrm{C}$ までの熱伝導度の差は極めて小 さい(15)

(4) Cr の適当量は 4.0 4.5\%であ ることに変りがなく，鋼種によつてほ とんど差がない、ソ連や欧州では高ク ロム (Cr 6〜12\%) のものが使われ, 欧 州では鋳造工具として使用せられてい る。同じ用途では高 $\mathrm{Cr}$ 高速度鋼は他 鋼種に比べて切削耐久力は低いが(16), Cr 高速度鋼のうちでは C 1.3 1.4\%， Cr 10\%,W 4\%, V 1\%, Co $5 \%$ のも
を座標軸にして，焙鈍状態の常温に拊ける相と焼入温度 に括ける相とを示した。第4 図には，それを重礼て1枚 に示してあるが，その実線は，焼入温度に和ける異なつ た相の境界を示し，破線は，焼鈍し状態に扣いて $\mathrm{M}_{3} \mathrm{R}_{2}$ (例 $\mathrm{Fe}_{3} \mathrm{~W}_{2}$ ) の現われる範囲と $\mathrm{M}_{23} \mathrm{C}_{6}$ の現われる範团と の境界を示した。 したがつて菀入温度で $\gamma+\mathrm{M}_{6} \mathrm{C}+\mathrm{MC}$ 範囲は焼鈍し状態では $\alpha+\mathrm{M}_{6} \mathrm{C}+\mathrm{MC}+\mathrm{M}_{23} \mathrm{C}_{6}$ であるこ とを示し， $\alpha+\mathrm{M}_{6} \mathrm{C}+\mathrm{MC}$ 範团で，破線より下は暁鈍し状 態で $\alpha+\mathrm{M}_{6} \mathrm{C}+\mathrm{MC}+\mathrm{M}_{3} \mathrm{R}_{2}$ であることを示している.

Wの低い高速度鋼では焼ワレを起しやすいが，Vを高 めるとワレがたくなり，5\% Co 高速度鋼では 4 5\% V で切削性能の向上が著しい(12). 高 $\mathrm{C}$ 高 $\mathrm{V}$ 高速度鋼では 低Wでも十分な焼入焼戻カタサが得られる。たと党ば C $1.2 \sim 1.6 \%$, W 5 9\%, Cr 4\%, V $5.5 \%$ で $1250^{\circ} \mathrm{C}$ 油焼 入, 適当に焼戻して最高 $\mathrm{HRC} 65$ が得られた ${ }^{(13)}$. 低Wで なければ HRC 66〜67 が得られ，さらにCo 10\% 添加， Wまたは Mo を少々高くすれば HRC 70 を得ることが出 来る・たと壳ば C 1.39\%,W 7.94\%, Mo 6.5\%, Cr 4.56 $\%$ ，V 3.42\%，Co 10\% で適当に焼入焼戻したるのは $\left(1220^{\circ} \mathrm{C}\right.$ 油焼入, $525^{\circ} \mathrm{C} \times 3$ 回焼戻 $)$ カタサ $\mathrm{HRC} 70$ 近? が得られ，切削耐久力も大さかつた ${ }^{(14)}$.

(3) Wについてはとくに新しい発展はなくて, 最高

(11) D. J. Blickwede, M. Cohen and G. A. Roberts: Trans. ASM, $42(1950), 1161$.

(12) W.Oertel: Metallwirtsch., 20 (1941), 579.

(13) 金子，佐藤：金属学会誌, 19 (1955), 59 .

(14) 沢: 鉄亡鋼, 50(1964), 676.
のの切削耐久力が高い(17). 高速度鋼で $\mathrm{Cr}$ 量が減ずる と，加熱のときのスケールの生ずる速さは 8 倍の早さで 増してくる.

(5) Co の添加は，高速度鋼の焼入温度を高くするこ とが出来るので, 焼入温度で $\gamma$ 相中に固溶する元素の量

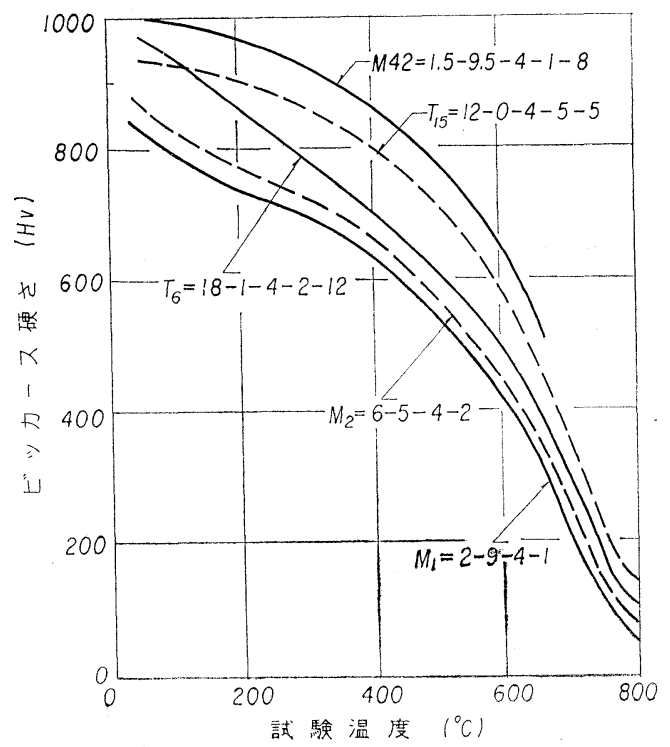

第 5 図高温カタサ (by G.A.Roberts, S.G.Hamaker, A.R.Johnson 追加してある)

(15) J. P. Gill and R. S. Rose : Metal Progress, 40 (1941) , 283.

(16) 小柴: 鉄と鋼, 34 (1948), No.9-18.

(17) 小柴: 鉄と鋼, 37 (1951), 532 . 
学多〉し，したがつて焼厌で高いカタサを得ることが出 来る、従来 Co を添加すると高温カタサが高いといわれ たが，実験の結果 Co の有無にかかわらず，常温カタサ の高い高速度鋼は概して高温でるカタサの高いことが示 された，第 5 図はいくつかの鋼種の高温カタサを示する ので, Co $12 \%$ を含むT 6 む，V $5 \%$ を含むT 15 上り高 温カタサは低くなつている。図には省略したが，T1は M 2 と重なり， T 5 は T 6 と M 2 との間にあつた。

(6) その他 Mn 2 3\% 飞高めると，高温カタサを 高めるが加工性を害し, $\mathrm{Cu} 0.5 \%$ 以上の添加は赤熱脆 性を生じ, 結晶粒成長を起しやすい。 また $\mathrm{Ni}$ の添加は 焼鈍軟化を困難にし，焼入状態で残留オーステナイトが 多く, 焼戻しても高いカタサが得にくい。しかし T 1 , M 2 に $3 \% \mathrm{Ni}$ 添加をし, サブゼ口処理を施したものは, 安定なオーステナイトを分解して, 谪当な焼戻カタサを 得ることが出来だ(18).

(18) R.F.Hehemann and A.R. Troiano: Iron Age, 182 (1958), No.25-94, No.26-52.

(19) 近藤：金属学会誌, 30 (1966), 124, 129 .

(20) H. J. French and T. G. Diggs: Trans. ASST, 8 (1925) , 681.

(21) A.K.Seal and R.W.K.Honeycombe: J.Iron Steel Inst., 188 (1958) , 343.

(22) 近藤：金属学会誌, $30(1966), 118$.

(23) 近藤：金属学会誌, 30 (1966), 112 .
（7）高C，高 V高速度鋼では，被研削性が著しく覀く なるので，Sを添加した高速度鋼が使用せられる，をた マシナビリティ改良するためにも添加せられる，普通 添加量は0.10 0.15\% であるが，特殊な場合にはさら に多量に加光てもよい(19).

(8) ソ連では高Nフェロクロムを溶鋼に添加した研究 飞执いて, 計算添加 $\mathrm{N}$ 量 $0.35 \%$ で鋼中含有 $0.10 \sim 0.15$ \% N であつたが，結晶粒成長が抑制せられ，熱間カタサ が高くなり，熱処理温度範囲が抎がり，鍛造性を害しな いで切削性能を増したとい5。調質鋼を切削して $62 \%$ の耐久力向上を得た。 そして $\mathrm{Al}$ や $\mathrm{Ti}$ のような窒化物 形成元素の存在で，工具としての効果が大きいという．

(9) $\mathrm{Ta}{ }^{(20)}, \mathrm{Nb}{ }^{(21)}$, Ti はともにVの代用になる. Ti の 添加は結晶粒を細くし, 焼入温度範囲を $30^{\circ} \sim 40^{\circ} \mathrm{C}$ 拡大 し，熱処理を容易にする。T1または M 2 高速度鋼厄 Ti を $2 \%$ 以下添加するときの最適C 量は

$$
\mathrm{C}(\%)=0.6 \%+0.2 \mathrm{~V}(\%)+0.4 \mathrm{Ti}(\%)
$$

であつて, Ti 量の增加とともに耐摩耗性と, 切削耐久 力が著しく向上する(22).これは Tiの添加によつて Ti と V を主成分とする $\mathrm{MC}$ 炭化物が生じ，V のみの $\mathrm{MC}$ 炭化物よりもその量が著しく増すためと考穴られる(23).

(つつく)

\section{特 許 䍘 報 (3)}

\section{$\diamond$ 昭和 41 年 4 月 25 日公告: 一}

粒状鉱石 および 精鉣からの金属直接製造法および装置 [昭 41-7761 優先権主張 1963.4.11 外 4 件 (各オースト ラリア) オーストラリアハワードノックスワーナー] 脱炭処理を必要としないクロマイジング用鋼〔昭 417762 千代田区 富士製鉄 K K ] C の活量を低下させる金 属元素を 1 種をたは 2 種以上を(5１5) $\times$ C \% 添加.

裏当剤を使用する鋼の片面突合わせ溶接法〔昭 41-7763 神戸市 KK神戸製鋼所]

\section{金属条片火花溶接部処理装置〔昭 41-7764 千代田区三} 菱重工業 K K]

アークスポット溶接棒 [昭 41-7765 港区 角丸工業 K K] $\mathrm{Fe}$ 粉 $20 \sim 45 \%$, 酸化チタン $20 \sim 35 \%$, 加里長石 10 20

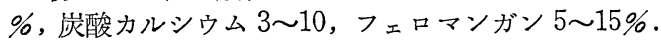
$\diamond$ 昭和 41 年 4 月 26 日公告: -

半導体の溶融装置〔昭 41-7921 優先権主張 1963.7.24 (独国) 独国 シーメンス ウント ハルスケ アクチェンゲ ゼルシャフト]

耐硫酸鋼 [昭 41-7923 神戸市 K K 神戸製鋼所〕 $\mathrm{wt} \% \mathrm{C}$ $0.02 \sim 0.8$, Si $0.15 \sim 1, \mathrm{Mn} 0.25 \sim 2, \mathrm{P}<0.02$, S 0.015 $\sim 0.05, \mathrm{Cu} 0.1 \sim 0.6$.

方向性の少ない高勒性 高張力鋼 [昭 41-7924 千代田区 富士製鉄 K K] wt\% C 0.06 0.2, Mn 0.3 1.5, $\mathrm{Cu}<$ $0.5, \mathrm{P}<0.1, \mathrm{Cr}<1, \mathrm{~A} 10.001 \sim 0.02, \mathrm{Nb} 0.005 \sim 0.1$,
残 $\mathrm{Fe}$.

オーステナイト系耐熱鋼；フェライト系耐熱鋼；オース テナイト系耐熱鋼 (関連 3 件) [昭 41-7925;7926; 7927 千代田区 K K 日立製作所] wt\% (1) C $0.05 \sim 0.2, \mathrm{Si} 0.2$ $\sim 1.2, \mathrm{Mn} 0.5 \sim 2.5, \mathrm{Ni} 8 \sim 12, \mathrm{Cr} 14 \sim 19, \mathrm{Mo} 1 \sim 2, \mathrm{Nb}$ $0.1 \sim 0.7$, V $0.1 \sim 0.6, \mathrm{~B} 0.02 \sim 0.15$ 残 Fe. (2) C 0.03 $\sim 0.09$, Si $0.1 \sim 1$, Mn 0.15 1, Cr 1 14, Mo 0.3 1.5, $\mathrm{Nb}<0.3, \mathrm{~V}<0.4, \mathrm{~W}<0.3, \mathrm{~B} 0.01 \sim 0.05$ 残 $\mathrm{Fe}$. (3) $\mathrm{C}$ $0.05 \sim 0.2$, Si $0.2 \sim 1.2$, Mn 0.5 2.5, Ni 8 12, Cr 14 $\sim 19, \mathrm{Mo1} 2, \mathrm{Nb} 0.1 \sim 0.5$ 残 $\mathrm{Fe}$.

高硬度アタマイトロールの製造法 [昭 41-7928 大阪市 久保田鉄工KK] wt\% C $1.2 \sim 2.5$, Cr $1 \sim 2$, Ni $1 \sim 5$, Mo 0.5〜1, Si 括よび Mn 0.5〜1残 Fe.

二方向性アルミニウム合金磁性板の製法[昭 41-7929 神戸市 $\mathrm{KK}$ 神戸製鋼所] 2 $6 \%$ の $\mathrm{Al}$ を含む $\mathrm{Fe}-\mathrm{A} 1$ 合 金材，または2〜6\%の A1 の半分以下をSiに置換した Fe-Al-Si 合金材の処理法.

半硬質磁性材料の製造法 [昭 41-7930 仙台市 東北金属 工業K K ] wt $\% \mathrm{Cu} 3 \sim 25$, 残 $\mathrm{Fe}$ 主成分に $\mathrm{Mn}, \mathrm{Cr}, \mathrm{Mo}$, $\mathrm{Ni}, \mathrm{Co}, \mathrm{Zr}, \mathrm{Ti} 1$ 種または数種 $<1, \mathrm{C}<0.5, \mathrm{~S}<0.1$ 冷間 圧延.

方向性けい素鋼帯の製造法 [昭 41-7931 千代田区 富士 製鉄 K K] wt\% Si 2.5 6, V 0.019 0.2.

けい苦ニッケル鉱などの処理法 [昭 41-7932 港区 日本 鉱業 $K K$ ]

金属間化合物磁石材料「昭 41-7933 門真市 松下電器産 